\title{
Outbreak
}

\section{Zika virus outbreak in Brazil}

\author{
Jorg Heukelbach ${ }^{1,2}$, Carlos Henrique Alencar ${ }^{1}$, Alyson Ann Kelvin ${ }^{3}$, Wanderson Kleber de Oliveira ${ }^{4}$, \\ Luciano Pamplona de Góes Cavalcanti ${ }^{1}$
}

${ }^{1}$ Department of Community Health, School of Medicine, Federal University of Ceará, Fortaleza, CE, Brazil

${ }^{2}$ Anton Breinl Centre for Public Health and College of Public Health, Medical and Veterinary Sciences, Division of Tropical Health and Medicine, James Cook University, Townsville, Australia

${ }^{3}$ Immune Diagnostics and Research (IDR), Toronto, Ontario, Canada

${ }^{4}$ Coordenação-Geral de Vigilância e Resposta às Emergências em Saúde Pública do Ministério da Saúde do Brasil, Brasilia, Brazil

\begin{abstract}
Zika virus (ZIKV) infection is spreading rapidly within the Americas after originating from an outbreak in Brazil. We describe the current ZIKV infection epidemic in Brazil and the neurological symptoms arising. First cases of an acute exanthematic disease were reported in Brazil's Northeast region at the end of 2014. In March 2015, autochthonous ZIKV was determined to be the causative agent of the exanthematic disease. As cases of neurological syndromes in regions where ZIKV, dengue and/or Chikungunya viruses co-circulate were reported, ZIKV was also identified in the cerebrospinal fluid of patients with acute neurological syndromes and previous exanthematic disease. By the end of September 2015, an increasing number of infants with small head circumference or microcephaly were noted in Brazil's Northeast which was estimated to be 29 cases between August and October. ZIKV was identified in blood and tissue samples of a newborn and in mothers who had given birth to infants with microcephaly and ophthalmological anomalies. In 2015, there were an estimated 440,000 - 1,300,000 Zika cases in Brazil. There have been 4,783 suspected cases of microcephaly, most of them in the Northeast of Brazil associated with 76 deaths. The Ministry of Health is intensifying control measures against the mosquito Aedes aegypti and implemented intensive surveillance actions. Further studies are needed to confirm the suspected association between ZIKV infection and microcephaly; to identify antiviral, immunotherapy, or prophylactic vaccine; to introduce diagnostic ELISA testing. Clinical and epidemiological studies must be performed to describe viral dynamics and expansion of the outbreak.
\end{abstract}

Key words: Zika virus; Flavivirus; Chikungunya; Dengue virus; Brazil; microcephaly.

J Infect Dev Ctries 2016; 10(2):116-120. doi:10.3855/jidc.8217

(Received 05 February 2016 - Accepted 16 February 2016)

Copyright (C) 2016 Heukelbach et al. This is an open-access article distributed under the Creative Commons Attribution License, which permits unrestricted use, distribution, and reproduction in any medium, provided the original work is properly cited.

\section{Introduction}

Zika virus (ZIKV) infection, previously unknown to the majority of physicians, public health professionals, and policy makers worldwide, is now spreading rapidly within the Americas originating from an outbreak in Brazil. On $1^{\text {st }}$ February 2016, the World Health Organization declared a Public Health Emergency of International Concern, considering the increasing number of ZIKV infection cases and a strongly suspected causal link between ZIKV infection and neurological disorders and congenital anomalies, which have increased recently in Brazil $[1,2]$. By the end of January 2016, there have been 18 countries in the Americas with confirmed autochthonous cases of Zika virus [3].

\section{The Virus}

ZIKV is a positive-sense, single-stranded (nonsegmented) RNA arbovirus of the flaviviridae family which is transmitted to humans by a bite from mosquitos of the genus Aedes [4,5]. The virus is related to other flaviviruses such as yellow fever virus (YFV), dengue virus (DENV), and Japanese encephalitis virus, but is mostly similar to the Spondweni virus. ZIKV is composed of $\sim 10,000$ nucleotides which encodes a polypeptide protein of $\sim 3,500$ aa [6].

There are two major lineages of ZIKV, Asian and African, which are composed of various sub-clades [5]. Although Aedes aegypti is the species of mosquito currently most associated with transmission, ZIKV has been isolated from a variety of other species of Aedes mosquitos including Ae. polynesiensis, Ae. albopictus, Ae. hensilli, Ae. africanus, Ae apicoargenteus, Ae. luteocephalus, Ae. vitattus, and Ae. furcifer $[5,6]$. ZIKV 
is transmitted to its vector host during the vector's blood meal. Once infected, the virus is then present in the vector host for the remainder of its lifespan, where it can be transmitted to reservoir hosts during subsequent blood meals.

ZIKV was isolated for the first time in 1947 from a sentinel rhesus monkey in the Zika forest of Uganda during a jungle fever study [7]. The main mode of transmission is considered to be vectorial although previous reports have indicated that the virus may be transmitted by other means including occupational, perinatal, and sexual intercourse $[8,9]$.

\section{Clinical disease of ZIKV infection}

The clinical presentation defining ZIKV infection is difficult to ascertain, as symptomology is often similar to that of DENV and Chikungunya virus (CHIKV) infections. Reported clinical signs associated with ZIKV infection include low grade fever, self-limiting rash lasting 4-7 days, conjunctivitis, headache, myalgia, and pruritus. Less commonly reported symptoms include retro-orbital pain, anorexia, vomiting, diarrhea and abdominal pain [5]. Despite the clinical symptoms reported, it is suspected that many cases are asymptomatic, which is problematic for estimating ZIKV infection incidence rates [5]. Before the recent outbreaks of the $21^{\text {st }}$ century, no severe complications were known, and hospitalization rates associated with ZIKV infection were low [10].

Diagnosis of ZIKV infection is typically done by RT-PCR of RNA isolated from patient blood samples collected less than 5 days following the onset of symptoms. Viremia in ZIKV patients is reported to occur between 3 and 5 days post symptom onset [8]. Moreover, live virus and viral RNA have also been detected in the semen and urine of Zika infected males weeks after initial symptoms and virus clearance in the blood. This report possibly suggests that uremia and semen viral loads are potentially longer lasting than blood viremia [8]. Diagnosis by ELISA is also difficult for suspected ZIKV cases, as neutralizing IgM antibodies are cross-reactive among the flaviviruses especially with DENV serotypes, which may lead to false ELISA results (US CDC, Centers for Disease Control and Prevention) [11]. Furthermore, crossreactivity may also affect retrospective studies aimed at determining the existing immunity of a particular population. Currently, specific treatments and prophylactics such as antivirals and vaccines for ZIKV infection and associated diseases do not exist.

\section{Previous ZIKV outbreaks}

Since the first description of ZIKV infection in the 1940 s, the virus was thought to cause mild sporadic human infections in Africa and Asia. This picture of ZIKV dramatically changed during the large-scale epidemics in Micronesia in 2007 and 2013-2014 in Yap and French Polynesia and New Caledonia, respectively [12-15]. Importantly, these epidemics in Micronesia simultaneously occurred along-side dengue fever cases (type 1 and 3 serotypes) [14,16]. During these outbreaks, neurological complications such as meningitis, meningoencephalitis and myelitis were reported. The appearance of these neurological symptoms were attributed to the concomitant circulation of the two dengue serotypes. Moreover, 42 cases of Guillain-Barré syndrome were diagnosed during the French Polynesia outbreak in patients who had presented symptoms of ZIKV infection $[3,10]$.

\section{History of the current outbreak in Brazil}

By the end of 2014, a few months after the Football World Cup in Brazil, reports of an acute exanthematic disease in various urban centers of Northeastern Brazil began to emerge [17,18]. From February 2015 onwards, other municipalities began notifying the Brazilian Ministry of Health of similar cases in their area. At the end of February 2015, the Ministry of Health (Secretary of Surveillance - SVS/MS) started monitoring the increasing number of an exanthematic disease in the Northeast Region of Brazil. All cases were reported to be self-limited, without any clinical interventions needed [19]. The patients presented with maculopapular exanthema, pruritus, low fever (or no fever), and in some cases headache, hyperemia of the conjunctiva, joint pain, and edema. The most commonly affected age group was $20-40$ years, with a range from 4 months to 98 years of age.

In March 2015, the Ministry of Health began to investigate the source of the outbreak and if the reported symptoms were caused by dengue fever, rubella, or Chikungunya fever. The preliminary results excluded infection by these pathogens. Later that month, ZIKV was isolated in Natal, capital of Rio Grande do Norte State [20], where 7 of 8 confirmed Zika cases were females (mean age 39 years), with similar signs and symptoms and fever presenting between 2 to 15 days [20]. In two of these cases, the strain of ZIKV was determined to be from the Asian lineage. During a similar time frame, ZIKV was isolated from samples collected from 7 patients with negative serology for DENV and CHIKV in the city of Camaçari in Bahia State $[21,22]$. Consequently, in May 2015, the Ministry 
of Health recognized autochthonous Zika transmission in the country, and standardized - in the absence of availability of validated ELISA testing - real-time polymerase chain reaction (RT-PCR) for the diagnostic investigation of suspected cases [19].

A few weeks later, in June of 2015, the Ministry of Health identified the first cases of neurological syndromes with a history of exanthematic disease in regions where Zika, dengue and/or Chikungunya viruses co-circulate. By the end of that month, the Ministry instructed the states of the Brazilian Federation to immediately report cases of neurological syndromes. Following this instruction, in July of 2015, Bahia State also filed cases of Guillain-Barré syndrome in patients with a history of exanthematic disease. Of the 76 notified Guillain-Barré syndrome cases, 42 were confirmed, and $26(62 \%)$ had a previous history of ZIKV or DENV infection. In Pernambuco State, ZIKV was identified in the cerebrospinal fluid of patients with acute neurological syndromes and previous exanthematic disease [23,24].

By the end of September 2015, reports surfaced of an increasing number of infants born with small head

Figure 1. Distribution of reported cases of ZIKV infection in Brazil by state, from the beginning of the outbreak (December 2014) until the end of January 2016.

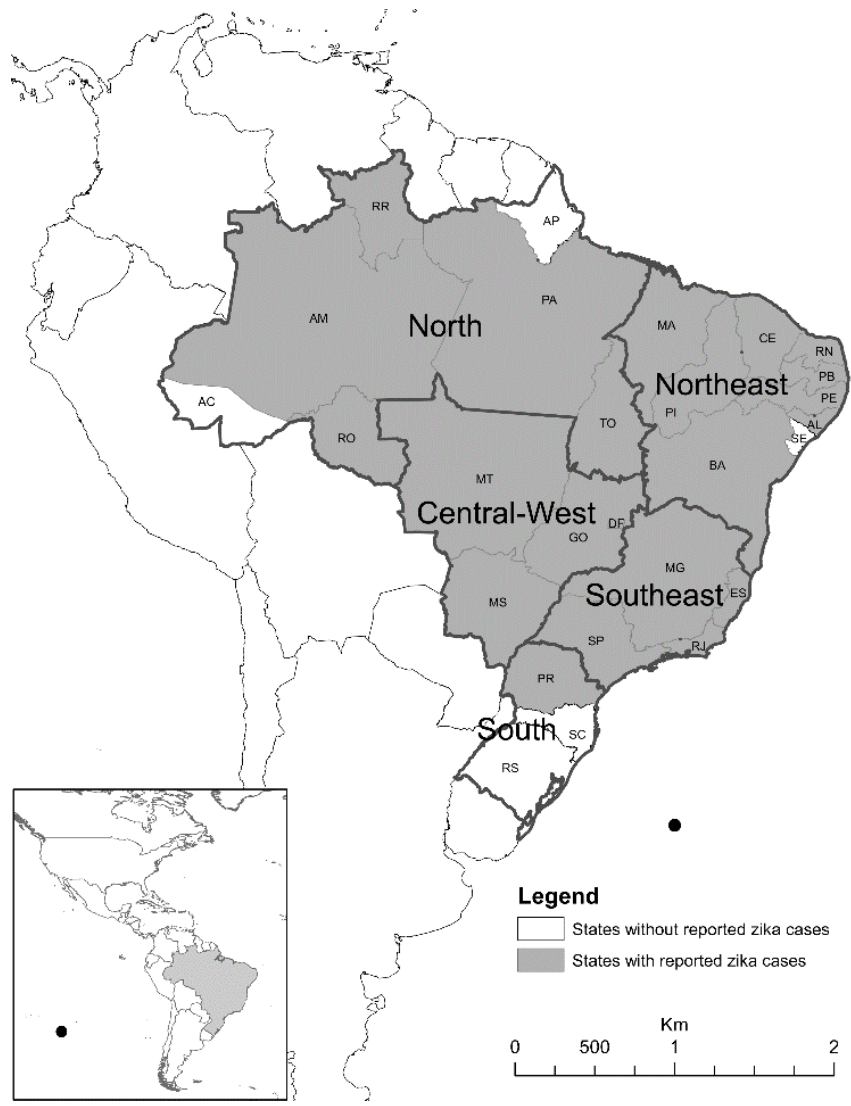

circumference or microcephaly from various healthcare facilities in Pernambuco State in the Northeast region ( 2 to 3 standard deviations below average for age and gender) [25]. By October, the State Health Secretariat of Pernambuco State (SES/PE) notified 29 cases of microcephaly in infants born since August. Taken together, these findings represent an extreme increase in microcephaly as compared to previous years $[25,26]$. On the $23^{\text {rd }}$ October 2015, the Brazilian Ministry of Health notified the World Health Organization about the occurrence of the increased number of infant microcephaly. On $12^{\text {th }}$ November, the Ministry of Health of Brazil published an order declaring a Public Health Emergency of National Importance (Emergência de Saúde Pública de importância Nacional - ESPIN), and on $17^{\text {th }}$ November, a technical note was also published. On $24^{\text {th }}$ November, ZIKV was identified in blood and tissue samples of a newborn from Ceará State, that had died in the postpartum period (Pamplona, personal communication 2016). After this incident, ZIKV was also isolated from the umbilical cord of a newborn and the Ministry of Health declared a possible association between ZIKV infection and the increasing number of microcephaly cases [27]. In

Figure 2. Distribution of reported cases of microcephaly in Brazil from July 2015 to February 2016.

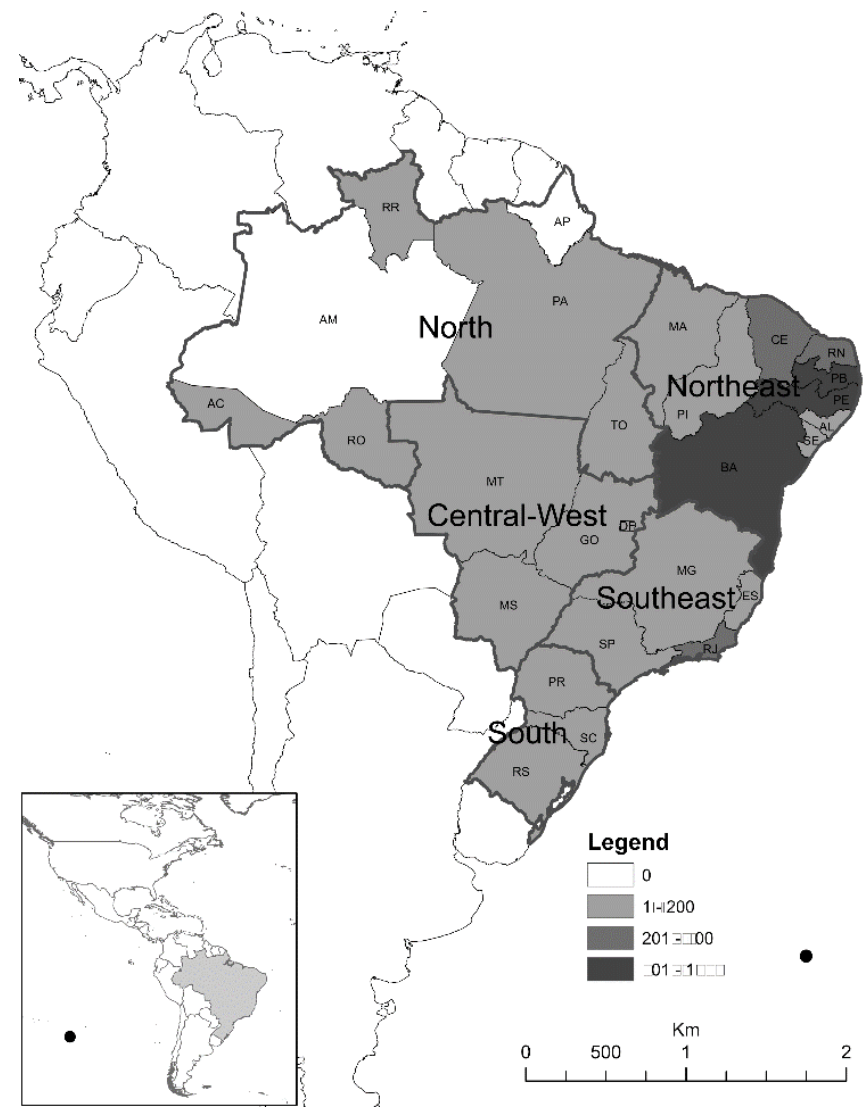


December 2015, guidelines for the management of microcephaly were published by the Ministry of Health [26]. In January 2016, three infants whose mothers had a history of ZIKV infection were diagnosed with microcephaly and ophthalmological anomalies. Additionally, one child also displayed neuroretinal atrophy [24].

It has been estimated that in 2015 there were between 440,000 and 1,300,000 Zika cases in Brazil. By $1^{\text {st }}$ February 2016, autochthonous cases of ZIKV were identified in 22 states of the Federation (Figure 1). Since the beginning of the outbreak, there have been 5,280 suspected cases of microcephaly, most of them in the Northeast of Brazil (Figure 2), with 108 deaths. By $13^{\text {th }}$ February 2016, 1,345 of the notified suspected cases had been investigated and classified, with 508 confirmed cases of microcephaly. In contrast, during the time period between 2010 and 2014, the annual mean of microcephaly cases reported in Brazil was 163.

The main vector carrying the ZIKV in Brazil has been identified as Aedes aegypti, the same mosquito species, which transmits DENV and CHIKV in Brazil. The Ministry of Health is currently intensifying control measures against the mosquito vector and implemented surveillance actions to identify possible areas of transmission as early as possible. Furthermore, neurological syndromes and congenital anomalies are under strict government surveillance. By Presidential Decree from $21^{\text {st }}$ December 2015, a National Task Force was installed, consisting of representatives from various Ministries, coordinated by the Ministry of Health [28]. The Brazilian Army was mobilized to support the community health agents in mosquito control measures, consisting of house-to-house visits and elimination of possible Ae. aegypti breeding sites. The aim is to visit all urban households in Brazil by the end of February 2016.

The co-circulation of ZIKV, DENV, and CHIKV in overlapping endemic regions of Brazil calls for special attention and highlights the urgent need for systematic studies and further laboratory, clinical, and epidemiological research.

\section{Future outlooks}

At this time, the current situation in Brazil leaves scientists, health care workers, and political leaders with addressing urgent action items, which encompass transmission, pathogenesis, and treatment of ZIKV. Most importantly, the suspected association between ZIKV infection and microcephaly must be confirmed scientifically. To decrease the expansion of ZIKV and its associated infection rate, the extremely rapid spread of the outbreak to other regions must be controlled. Currently, there is no specific treatment for ZIKV infection which prompts the identification of an antiviral, immunotherapy, or prophylactic vaccine. As ELISA testing is still not available, the estimation of ZIKV infected individuals is not feasible. It is essential to introduce a Zika antibody ELISA testing kit on a large scales as fast as possible. Finally, there are only very limited clinical and epidemiological data including the geographical spread and expansion of the outbreak. We need to have a better understanding of the viral dynamics in the environment and human population to design appropriate and effective control measures.

\section{References}

1. Ministério da Saúde- Brasil (2015) Ministério da Saúde confirma relação entre vírus Zika e microcefalia. Brasília: Ministério da Saúde. Available from: http://portalsaude.saude.gov.br/index.php/cidadao/principal/a gencia-saude/21014-ministerio-da-saude-confirma-relacaoentre-virus-zika-e-microcefalia. Accessed on February 03, 2016.

2. WHO (2016) WHO Director-General summarizes the outcome of the Emergency Committee regarding clusters of microcephaly and Guillain-Barré syndrome. Geneva: World Health Organization; Available from: http://www.who.int/mediacentre/news/statements/2016/emerg ency-committee-zika-microcephaly/en/. Accessed on February 03, 2016.

3. PAHO (2016) Epidemiological Update Neurological syndrome, congenital anomalies, and Zika virus infection. PAHO; Available from: http://www.paho.org/hq/index.php?option=com_docman\&tas $\mathrm{k}=$ doc_view\&Itemid $=270 \& \mathrm{gid}=32879 \&$ lang $=\mathrm{en}$. Accessed on February 03, 2016.

4. Marcondes CB, Ximenes MdFFd (2015) Zika virus in Brazil and the danger of infestation by Aedes (Stegomyia) mosquitoes. Rev Soc Bras Med Trop AHEAD.

5. Ioos S, Mallet H-P, Goffart IL, Gauthier V, Cardoso T, Herida M (2014) Current Zika virus epidemiology and recent epidemics. Medecine et maladies infectieuses 44:302-307.

6. Hayes EB (2009) Zika virus outside Africa. Emerg Infect Dis 15:1347-1350.

7. Dick G, Kitchen S, Haddow A (1952) Zika virus (I). Isolations and serological specificity. Trans R Soc Trop Med Hyg 46: 509-520.

8. Musso D, Roche C, Robin E, Nhan T, Teissier A, CaoLormeau V-M (2015) Potential sexual transmission of Zika virus. Emerg Infec Dis 21:359.

9. Foy BD, Kobylinski KC, Chilson Foy JL, Blitvich BJ, Travassos da Rosa A, Haddow AD, Lanciotti RS, Tesh RB (2011) Probable non-vector-borne transmission of Zika virus, Colorado, USA. Emerg Infect Dis 17: 880-882.

10. ECDC European Centre for Disease Prevention and Control (2014) Rapid risk assessment: Zika virus infection outbreak, French Polynesia. Stockholm: ECDC; 12 p.

11. CDC (2016) Updated diagnostic testing for Zika, chikungunya, and dengue viruses in US Public Health Laboratories. United States: CDC, Division of Vector-Borne Diseases, (2016) 
Arboviral Diseases and Dengue Branches. Accessed on February 05, 2016.

12. Duffy MR, Chen T-H, Hancock WT, Powers AM, Kool JL, Lanciotti RS, Pretrick M, Marfel M, Holzbauer S, Dubray C (2009) Zika virus outbreak on Yap Island, federated states of Micronesia. N Engl J Med 360: 2536-2543.

13. Heang V, Yasuda CY, Sovann L, Haddow AD, Travassos da Rosa AP, Tesh RB, Kasper MR (2012) Zika virus infection, Cambodia, 2010. Emerg Infect Dis 18: 349-351.

14. Cao-Lormeau V-M, Roche C, Teissier A, Robin E, Berry A-L, Mallet H-P, Sall AA, Musso D (2014) Zika virus, French polynesia, South pacific, 2013. Emerg Infec Dis 20:2.

15. Roth A, Mercier A, Lepers C, Hoy D, Duituturaga S, Benyon E, Guillaumot L, Souares Y (2014) Concurrent outbreaks of dengue, chikungunya and Zika virus infections-an unprecedented epidemic wave of mosquito-borne viruses in the Pacific 2012-2014. Euro Surveill 19: 20929.

16. Dupont-Rouzeyrol M, O'Connor O, Calvez E, Daures M, John M, Grangeon J-P, Gourinat A-C (2015) Co-infection with Zika and dengue viruses in 2 patients, New Caledonia, 2014. Emerg Infect Dis 21: 381 .

17. Caxias (2015) Secretário de Saúde adota providências sobre surto de virose em Caxias. Caxias County; Available from: http://caxias.ma.gov.br/noticia/secretario-de-saude-adotaprovidencias-sobre-surto-de-virose-em-caxias. Accessed on February 03, 2016.

18. Aracaju (2015) Saúde de Aracaju esclarece boatos de epidemia. Available from: http://www.infonet.com.br/saude/ler.asp?id=169244. Accessed on February 03, 2016.

19. Ministério da Saúde - Brasil (2015) Protocolo de atenção à saúde e resposta à ocorrência de microcefalia relacionada à infecção pelo vírus Zika. Brasília: Ministério da Saúde. Secretaria de Atenção à Saúde; 2015. 49 p.

20. Zanluca C, Melo VCAd, Mosimann ALP, Santos GIVd, Santos CNDd, Luz K (2015) First report of autochthonous transmission of Zika virus in Brazil. Mem Inst Oswaldo Cruz 110: 569-572.

21. Campos GS, Bandeira AC, Sardi SI (2015) Zika virus outbreak, Bahia, Brazil. Emerg Infect Dis 21: 1885.

22. Cardoso CW, Paploski IA, Kikuti M, Rodrigues MS, Silva MM, Campos GS, Sardi SI, Kitron U, Reis MG, Ribeiro GS
(2015) Outbreak of exanthematous illness associated with Zika, chikungunya, and dengue viruses, Salvador, Brazil. Emerg Infect Dis 21:2274.

23. Oliveira Melo A, Malinger G, Ximenes R, Szejnfeld P, Alves Sampaio S, Bispo de Filippis A (2016) Zika virus intrauterine infection causes fetal brain abnormality and microcephaly: tip of the iceberg? Ultrasound in Obstetrics \& Gynecology 47: 67.

24. Ventura CV, Maia M, Bravo-Filho V, Góis AL, Belfort R (2016) Zika virus in Brazil and macular atrophy in a child with microcephaly. The Lancet 387:228.

25. Secretaria Estadual de Saúde de Pernambuco (2015) Protocolo Clínico e Epidemiológico para investigação de casos de microcefalia no estado de Pernambuco. Recife: Secretaria Estadual de Saúde de Pernambuco. Secretaria Executiva de Vigilância em Saúde.

26. Ministério da Saúde- Brasil (2015) Protocolo de vigilância e resposta à ocorrência de microcefalia. Brasilia: Ministério da Saúde - Secretaria de Vigilância em Saúde; 2015 December 9, $55 \mathrm{p}$.

27. Schuler-Faccini L (2016) Possible Association Between Zika Virus Infection and Microcephaly-Brazil, 2015. MMWR Morb Mort Wkly Rep 65.

28. Ministério da Saúde - Brasil (2016) Saúde investiga 3.670 casos suspeitos de microcefalia no país. Brasília: Ministério da Saúde - Secretaria de Vigilância em Saúde; Available from: http://portalsaude.saude.gov.br/index.php/cidadao/principal/a gencia-saude/22032-saude-investiga-3-670-casos-suspeitosde-microcefalia-no-pais. Accessed on February 03, 2016.

\section{Corresponding author}

Jorg Heukelbach

Department of Community Health, School of Medicine, Federal University of Ceará, Rua Professor Costa Mendes 1608, 5. andar, Fortaleza CE 60430-140, Brazil

Phone: +55853366.8045

Email: heukelbach@web.de

Conflict of interests: No conflict of interests is declared. 